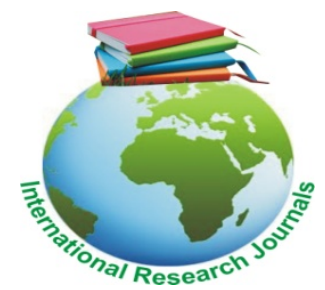

African Journal of Food Science and Technology (ISSN: 2141-5455) Vol. 6(4) pp. 108-117, July, 2015

Available online @http://www.interesjournals.org/AJFST

DOI: http:/dx.doi.org/10.14303/ajfst.2015.039

Copyright @2015 International Research Journals

Full Length Research Paper

\title{
Harnessing of banana ripening process for banana juice extraction in Uganda
}

\author{
Godfrey Omulo, Noble Banadda, *Nicholas Kiggundu \\ Department of Agricultural and Bio-system Engineering, Makerere University, P.O. Box 7062 Kampala, Uganda \\ *Corresponding author's email: kiggundu@caes.mak.ac.ug
}

ABSTRACT

\begin{abstract}
Banana is a very important staple food crop in Uganda. It is grown in every part of the country with the largest production recorded in western and central regions. Uganda is ranked the second largest producer of banana after India in the world. Bananas produced in Uganda are largely consumed locally as matookewith small amounts being exported as green banana or ripened to make juice, wine, beer or chips. There are variousmanual techniques of making banana juices in Uganda ranging from hands, foot and small scale mechanical machines which are not economical and hygienic. However, banana ripening poses a very big challenge to farmers and small scale processors. This has resulted in large quantities of banana loss, reduced shelf life and low economic returns to small scale farmers. In this review, different methods of natural, controlled banana ripening and ripening delay techniques are outlined. Controlled ripening of bananas is a key facet to good economic return in banana production as well as a stable and feasible strategy to ensure constant supply of ripe banana for banana juice processing.
\end{abstract}

Keywords: Banana, Natural ripening, Controlled ripening, Delayedripening, Shelf life

\section{INTRODUCTION}

Banana (Musa spp.) is tropical fruit belonging to the Musaceae family. It is the fourth world's most important food crop after rice, wheat and corn (Mahajan et al., 2010). Banana is grown in small scale farms in developing countries where it contributes highly to socioeconomic gain of the farmers because of its long production period. Banana production begins 14 months after planting and can yield up to 10 years, thus continuous harvesting of banana throughout the year provides the farmers with constant income source (Beer and Sigawa, 2010). Banana is the most consumed fruit in the world due to its nutrients composition; vitamins, mineralsand energy as shown in and also it is an important staple food worldwide (Adão and Glória, 2005).

Uganda is the second world's largest producer and consumer of banana with acountry's population of 36.6 million (Uganda Bureau of Statistics UBoS, 2014). The country's total area is $24,155,070$ ha with $15.1 \%$ of the total land covered by open water bodies, $1.9 \%$ covered by wetlands and the remaining $83.0 \%$ being the dry land area (UBoS, 2014). The total agricultural land is $9,115,180$ ha which is $45.5 \%$ of the total dry land (UBOS, 2014). The country has different ecological zones and farming systems for various crops as shown in According to FAO (2013), banana production in Uganda (including plantain) is estimated at $4,375,000$ metric tonnes (MT) per year. The production varies depending on the region and districts of growth as illustrated in Figure 1.

The bananas produced in the western region contribute to about $61 \%$ of the country's total production (Komarek, 2010).The districts with the highest banana production per region are as follows; Isingiro (western) with 601,363 tonnes; Mubende (Central) with 204, 109 tonnes; Mbale (Eastern) with 
Omulo et al. 109

Table 1. Nutritional composition of raw banana (USDA National Nutrion Database ,2014).

\begin{tabular}{|c|c|c|c|}
\hline Nutient and unit & Value & Nutrient and unit & Value \\
\hline \multicolumn{4}{|l|}{ Proximate (\%) } \\
\hline Water & 74.91 & Riboflavin (mg) & 0.073 \\
\hline Energy (kcal) & 89 & Niacin $(\mathrm{mg})$ & 0.665 \\
\hline Protein $(\mathrm{N} \times 6.25)$ & 1.09 & Pantothenic acid (mg) & 0.334 \\
\hline Total lipid (fat) & 0.33 & Vitamin B-6 (mg) & 0.367 \\
\hline Ash & 0.82 & Choline, total (mg) & 9.8 \\
\hline Carbohydrate, by difference & 22.84 & Betaine (mg) & 0.1 \\
\hline Fiber, total & 2.6 & Vitamin A, RAE (mog_RAE) & 3 \\
\hline Sugars, total & 12.23 & Phytosterols (mg) & 16 \\
\hline Sucrose & 2.39 & Carotene, beta (mog) & 26 \\
\hline Glucose (dextrose) & 4.98 & Vitamin A, IU (IU) & 64 \\
\hline Fructose & 4.85 & Vitamin E (alpha-tocopherol) (mg) & 0.10 \\
\hline Starch & 5.38 & & \\
\hline Mineral (mg/100 g) & & Lipid (\%) & \\
\hline Calcium, Ca & 5 & Fatty cids, total saturated & 0.112 \\
\hline Iron, $\mathrm{Fe}$ & 0.26 & Fatty cids, total monosaturated & 0.032 \\
\hline Magnesium, Mg & 27 & Fatty acids, tptal polyunsaturated & 0.073 \\
\hline Phosphorus, $\mathrm{P}$ & 22 & & \\
\hline Potassium, $\mathrm{K}$ & 358 & Amino acid (\%) & \\
\hline Sodium, $\mathrm{Na}$ & 1 & Leucine & 0.068 \\
\hline Zinc, Zn & 0.15 & Lysine & 0.050 \\
\hline Copper, Cu & 0.078 & Phenylalanine & 0.049 \\
\hline \multirow[t]{3}{*}{ Manganese, Mn } & 0.270 & Valine & 0.047 \\
\hline & & Arginine & 0.049 \\
\hline & & Histidine & 0.077 \\
\hline Vitamin & & Alanine & 0.040 \\
\hline Vitamin C, total ascorbic acid (mg) & 8.7 & Aspertic acid & 0.124 \\
\hline Thiamin (mg) & 0.031 & Glutamic acid & 0.152 \\
\hline
\end{tabular}

99,011 tonnes; and Arua (Northen) with 17,106 tonnes per annum (UBoS, 2014).

Banana production in Uganda is mainly done by smallholder farmers with the total area harvested being 972,000 hectares which is $17 \%$ of the total area occupied by food crops $(5,743,000$ ha), as shown in Figure 2. (UBoS, 2014). This make banana the most widely cultivated crop in the country.

The commonly grown varieties are the cooking banana (matooke) type of East African highland banana (EAHB) subgroup, the dessert bananas such as Sukali Ndizi and Bogoya and plantain species for roasting and Kayinja and Kisubiwhich are the most suitable for making fresh banana juice, wine and beers because they possess high concentration of natural sugars (Bagamba and Burger, 2007). Production of cooking banana (locally known as matooke) is approximated at $29.5 \%$ of the world's banana production while dessert banana production is estimated to be $0.85 \%$ of global production (REFORUM et al., 2010).

\section{Banana ripening process}

As a climacteric fruit, banana is harvested while mature greenand then allowed to either ripen naturally or induced to ripen. The ripening process breaks down chlorophyll revealing the carotid pigments thereby yielding the golden yellow colour of the ripe fruit. This occurs as a result of normal climatic respiration and production of ethylene gas at temperature between $20^{\circ} \mathrm{C}$ to $30^{\circ} \mathrm{C}$ (Yang et al., 2009).

During respiration, complex carbohydrate substrates are broken down to simpler molecules of carbon dioxide $\left(\mathrm{CO}_{2}\right)$ and water $\left(\mathrm{H}_{2} \mathrm{O}\right)$. Respiration steps include glycolytic pathway of the cytoplasm, the tricarboxylic acid 


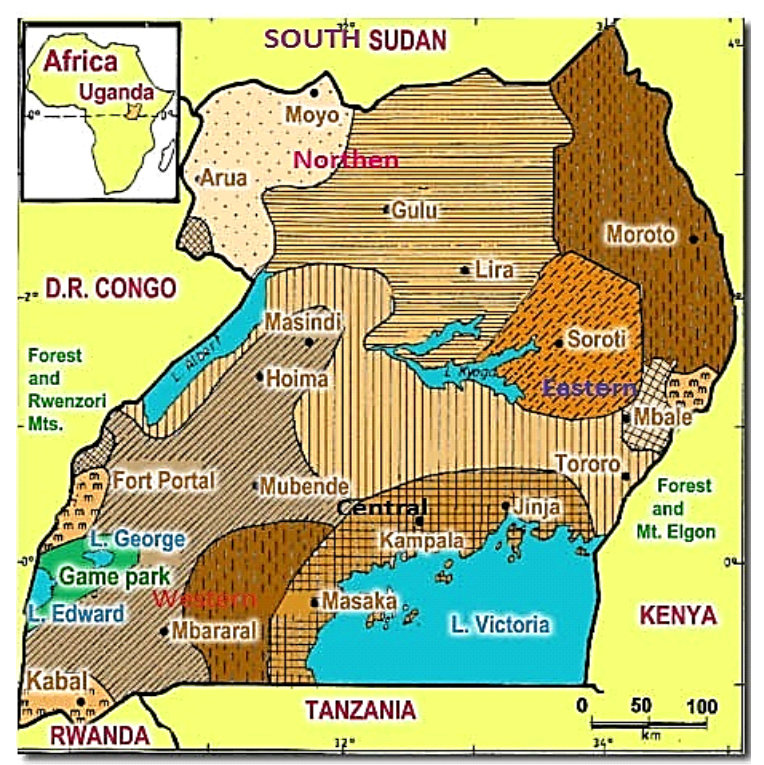

Lege nd

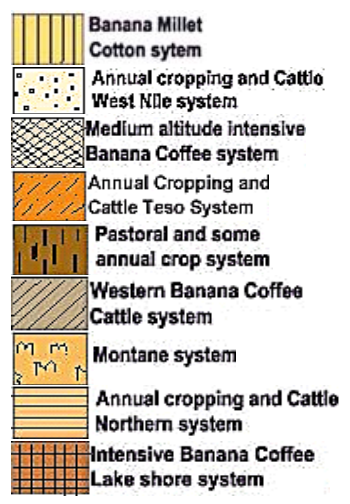

Figure 1. A map showing farming system in Uganda with interest in banana growing areas.

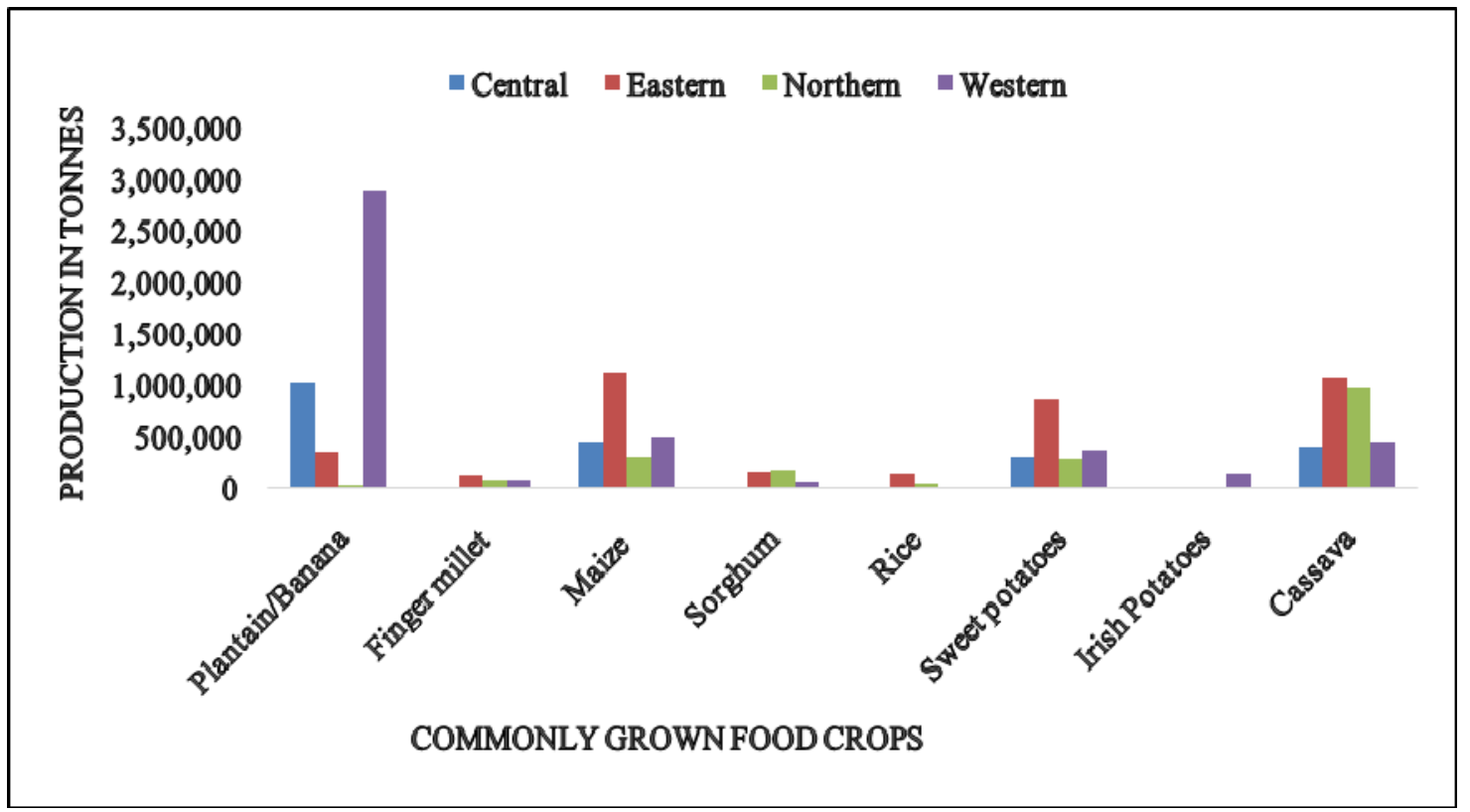

Figure 1. Production of Banana in comparison to other food crops in different regions of Uganda in 2013. Source:(UBOS and MAAIF, 2013).

cycle, pentose phosphate pathway and electron transport system, respectively (Sen, 2012). Since banana is a climacteric fruit there is a sudden increase of respiration rate during ripening as shown in Figure 3 , which leads to bursting of ethylene production at the onset of climacteric peak. This is enzyme controlled (Salveit, 2004).

\section{Precooling and delayed ripening of bananas}

According to Imahori et al. (2013),mature green banana fruitscan be curbed from ripening during storage and transportation. Pre-cooling of bananas to $13^{\circ} \mathrm{C}$ by use of refrigeration techniques maintain a low temperature 


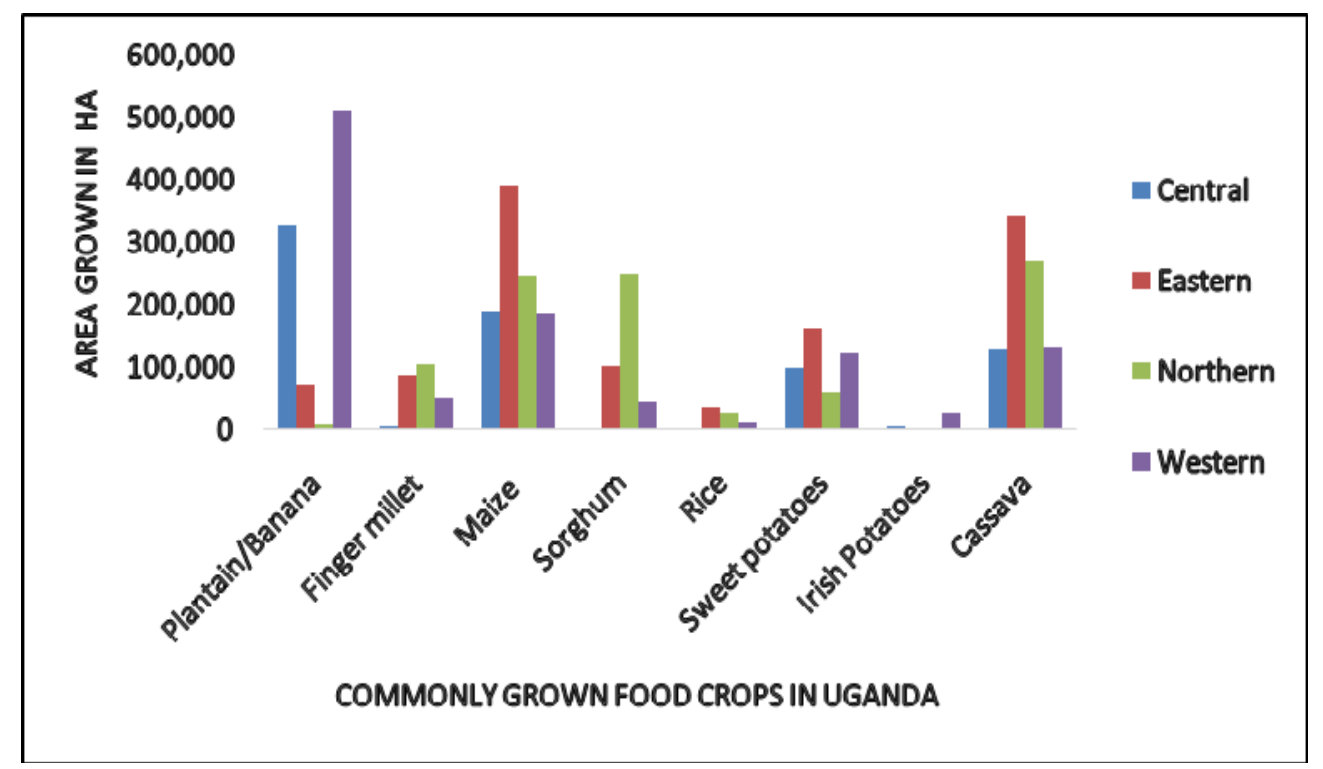

Figure 2. Area in Ha of commonly grown food crops in Uganda in 2013. Source: (UBOS and MAAIF, 2013).

during the storage period.Controlled atmospheres (CA) and modified atmospheres (MA) extend the storage life of mature green bananas (Palomeret al., 2005) by reducing metabolic rate; peel de-greening and limiting fruit's decay. Similarly, low oxygen pre-treatment can delay ripening of bananas during storage and transportation by exposing mature green banana fruits to low Oxygen $\left(\mathrm{O}_{2}\right)$ for two days (Imahori et al., 2013). However, these processes arevery costly to the small scale farmers in developing countries especially Uganda and thus an alternative low-cost method that delays ripening would be useful.

In Uganda, many small scale farmers rely on natural ripening of banana. This is very uneconomical and unsustainable for banana juice extraction processing. As a result, many ripened bananas are spoilt and lost due to poor storage and ripening conditions. This paper seeks to review existing banana ripening and delay techniques and how they can be applied to small scale farmers in Uganda. In addition, the paper seeks to explore the feasibility of harnessing controlled banana ripeningto sustain banana juice extraction in Uganda.

\section{Overview Of Banana Ripening Techniques And Their Relevance To Uganda}

\section{Natural Ripening}

Mature banana fruits ripen naturally due to climatic respiration and production of ethylene gas (Yang et al.,
2009).Banana is largely ripened naturally in Uganda through several traditional methods. Hanging the bunches on racks in cool dry stores or digging pits out on farms and covering banana bunches with leaves are some of the techniques used in ripening. Under these conditions the banana ripened are generally not satisfactory for juice processing since the bananas are ripened at poor hygiene and at uncontrolled temperatures (KyamuhangireandPehrson, 1999).

According to Kyamuhangire et al. (2002), Ugandan Kayinja bananas (ABB genotype) used majorly for juice extraction is harvested at maturity based on the fullness of the fingers. The bananas are put in the ripening room at $28^{\circ} \mathrm{C}$ and $90-95 \% \mathrm{RH}$ without the use of ethylene until the peel becomes completely yellow, about stage 7 , visual scale. Natural banana ripening produces natural quality ripened bananas althoughis not reliable and cannot be sustainable for large scale juice extraction process. Similarly, large quantities of banana are wasted due to uncontrolled nature of natural ripening.

\section{Controlled ripening}

\section{Treatment with Ethylene and Ethephon gases}

Ethylene is a colourless, odourless and tasteless gas introduced to plants as hormonesin very small amounts (parts per million)(Senet al., 2012), while ethephon gas is converted to ethylene gas upon metabolism by plants, and they are used for banana ripening.According to 


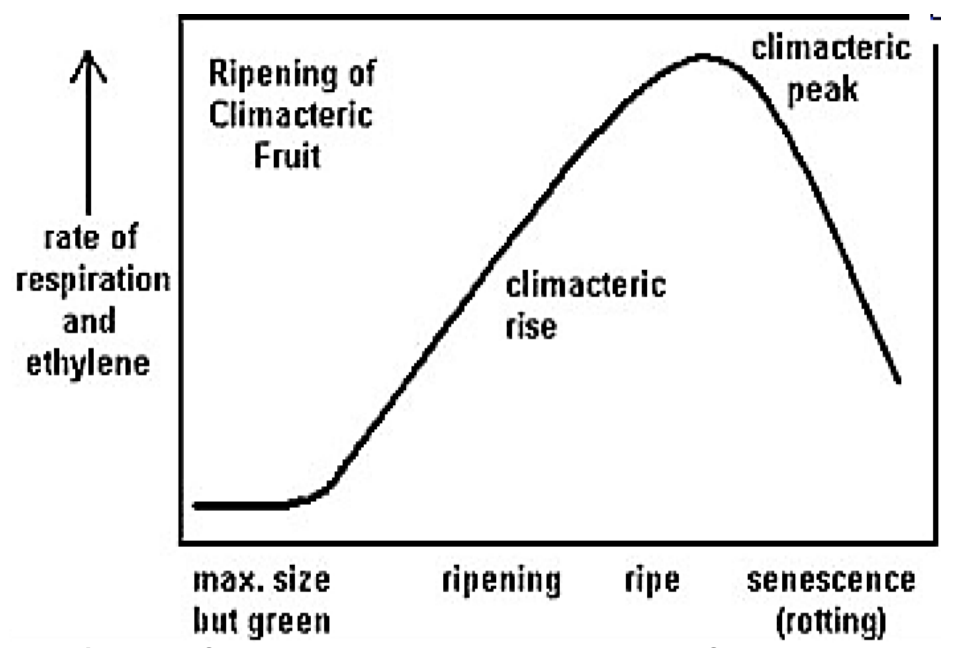

Figure 3. Climacteric vs Non-climacteric Ripening (Salveit, 2004).

(Mahajan et al., 2010), banana fruits are harvested at green mature stage and kept under the shed slanting in a way to improve delatexing and to prevent blackening of banana fingers. Consequently, these bananas areexposed to ethylene gas (100 ppm) for 24 hours using portable ethylene gas generator inside the ripening chamber maintained at $18^{\circ} \mathrm{C}$ and $90-95 \%$ relative humidity $(\mathrm{RH})$. Similarly, the bananas can be likewise dipped in aqueous solutions of ethephon in different proportions for a period offive minutes.

These treated bananas are then dried by air and stacked in plastic crates then put in ripening chambers maintained at $18^{\circ} \mathrm{C}$ and $90-95 \% \mathrm{RH}$ (Mahajan et al., 2010). The ethylene and ethephon gases result in adequate ripening of banana fruits within four days, with uniform colour, pleasant flavour, desirable firmness and acceptable quality and better shelf-life(Larotonda et al., 2008).

These techniques have been used in India (Mahajan et al., 2010), Brazil (Larotonda et al., 2008) and Australia (Will et al., 2001), but not in Uganda. Therefore, these techniques of banana ripening can be a good strategyto boost the capacity of banana ripening for juice extraction in Uganda thereby improving the productivityof small scale farmers.

\section{Using Edible Coatings}

In this technique, varied percentages of chitosan, gibberellic acid 100 ppm, jojoba wax, and glycerol (98\%) coatings are applied to mature banana fruits before being stored at a temperature of $34 \pm 1^{\circ} \mathrm{C}$ and $70-75 \% \mathrm{RH}$. These coatings prevent weight loss, decay, total soluble solids, $\mathrm{pH}$, sugar accumulation, pigment degradation and ascorbic acid of the bananas more than the uncoated ones. This technique prolongs banana shelf life, controls decay percentage and improves postharvest quality characteristics of bananas (Gol andRao, 2011).

This technique is mostly done in India ( $\mathrm{Gol}$ andRao, 2011)and Indonesia (Suseno et al., 2014)though not in use in Uganda. It is a very feasible method of managing decay, weight loss and ripening of banana. Thus in Uganda it can be very useful not only for controlled ripening but also for increasing the shelf life of banana for export.

\section{Overview Of Ripening Delay Techniques And Their Relevance To Uganda}

\section{Modified Atmosphere Packaging (MAP)}

Once bananas are harvested they require good hygienic handling. Modified atmosphere packaging (MAP) techniques help to minimize thephysiological and microbial decay. According to Sen et al., 2012, Modified Atmosphere (MA) is different from the normal air since its compositions are not the same. Therefore,MAP cancontrol the physiological and microbial decay of perishable fruits. The modification of internal atmosphere composition takes place at total pressure or partial pressures levels of gas components by either directly flushing the gas or by respiration of the enclosed product.

There is a continuous depletion of oxygen $\left(\mathrm{O}_{2}\right)$ in respiring fruits with the increase of carbon dioxide $\left(\mathrm{CO}_{2}\right)$ and water vapour creating a passive MAP. If the required gas composition mixture is introduced to package area after evacuation or by a continuous flow of gas mixture to replace the air, it creates an active MAP(GonzalezAguilar et al., 2010). MAP technique is used widely in commercial banana transportation especially in India 


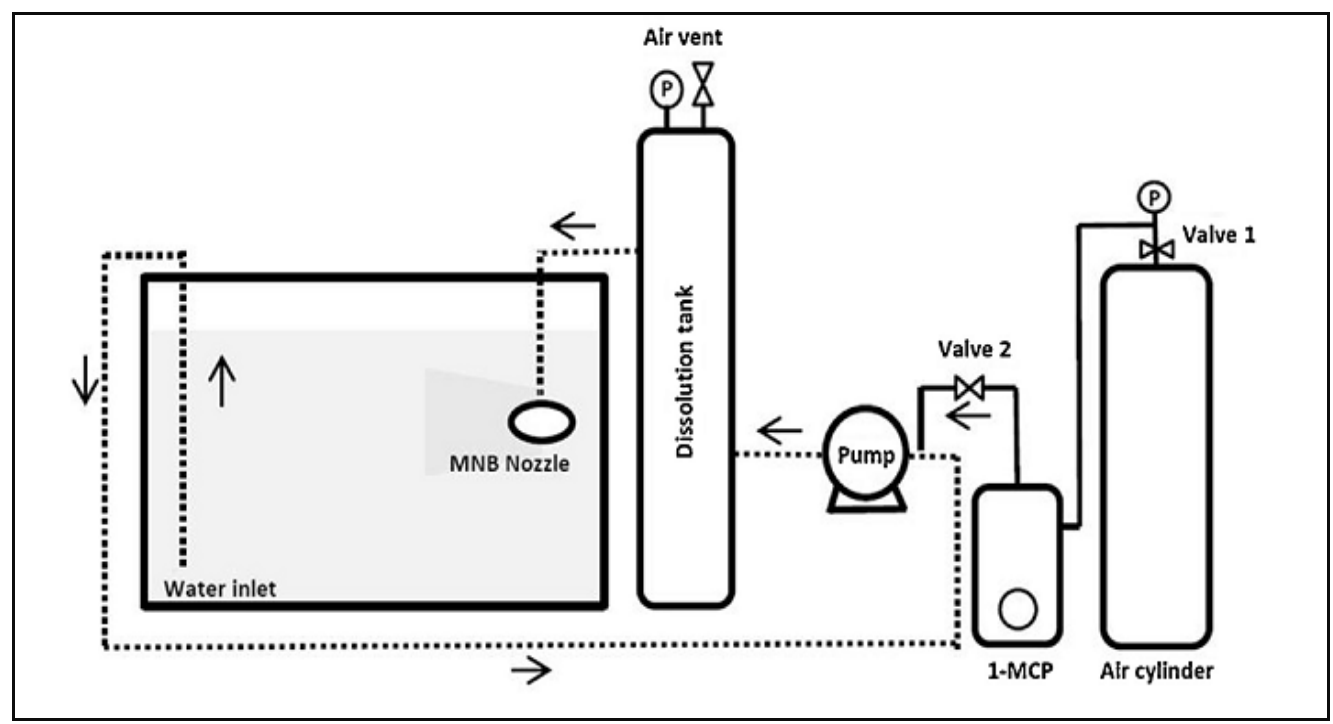

Figure 4. Schematic diagram of 1-MCP microbubble generation system.

Source:(Pongprasertand Srilaong, 2014).

(Sen et al., 2012), Jamaica, Canada (Stewart et al., 2005), Uruguay and Chile (Silveiraet al., 2014)though it is not yet used in Uganda. MAP of banana fruits increase their shelf life with minimal effect on the qualityduring handling, transportation and storage, thus can be very useful if used by farmers in Uganda to improve their income.

\section{Treatment with high Nitrous oxide $\left(\mathrm{N}_{2} \mathrm{O}\right)$ and low Oxygen $\left(\mathrm{O}_{2}\right)$ combinations}

A combinationof nitrous oxide $\left(\mathrm{N}_{2} \mathrm{O}\right)$ andreduced levels of oxygen $\left(\mathrm{O}_{2}\right)$ have an effect on the postharvest ripening ofmature green banana fruit. The fruits are stored at a room temperature of $20^{\circ} \mathrm{C}$, in a flow-through system, to various proportions of $\mathrm{N}_{2} \mathrm{O}$ and $\mathrm{O}_{2}$ for 10 days (Palomer et al.,2005). $\mathrm{N}_{2} \mathrm{O}$ delays banana fruit ripening significantly as evaluated by ethylene synthesis and respiration associated with changes in colour, acidity and softening.

This ripening delay technique is widely used in Europe especially in Spain (Palomer et al.,2005) and also in China (Cheng et al., 2008)though it has not been used in Uganda. This technique similarly is a potential tool that can be used to improve the shelf life of banana fruits and thus improve ripening in turn improving the potential of banana juice extraction.

\section{ControlledTemperature and Air Flow Rate Method}

Exposing banana to low temperaturesextends the greenlife of the fruit by reducing the metabolic rate of the fruit, consequently deteriorating senescence and decay
(Peroni-Okita et al., 2013). The shortest shelf life of banana at low temperature of $15^{\circ} \mathrm{C}$ to $21^{\circ} \mathrm{C}$ and airflow rate of $0.3 \mathrm{~m}^{3} / \mathrm{s} . \mathrm{kg}$ is between 12 and 25 days (Abdallah, 2012). Therefore, subjecting bananas to low temperatures slows ripening rate and increases their shelf life(Bagnato et al., 2002).This technique is most commonly used worldwide for precooling and controlled ripening(Der-Agopian et al., 2011). In Uganda it is used especially to extend the lifespan of the matookewhich are exported to USA and Europe(UBoS, 2014).

\section{Novel Technique of using 1-Methylcyclopropene (1- MCP) Micro Bubbles}

This technique uses micro bubble technology to delay the ripening of banana. During banana ripening, 1Methylcyclopropene (1-MCP) is used in the form of aqueous micro bubble (MBs) solution. The banana fruits are then dipped in500 nL/L ${ }^{-1}$ of aqueous 1-MCP microbubbles (1-MCP-MBs) as in Figure 4 or fumigated with $500 \mathrm{~nL} / \mathrm{L}^{-1} 1-\mathrm{MCP}$. They are then storedin ripening chamber at $25{ }^{\circ} \mathrm{C}$ for eight days(Pongprasert and Srilaong, 2014). According to (Harris et al., 2000), it is a very effective techniquein delaying the postharvest ripening of bananas because 1-MCP-MBs reducesthe respiration rate and production of ethylene. Similarly, it slowed yellowingmaintaining firmness of banana fruit during storage. It is majorly used in Thailand (Pongprasert and Srilaong, 2014) and Australia (Harris et al., 2000) but not much in Africa especially Uganda. 


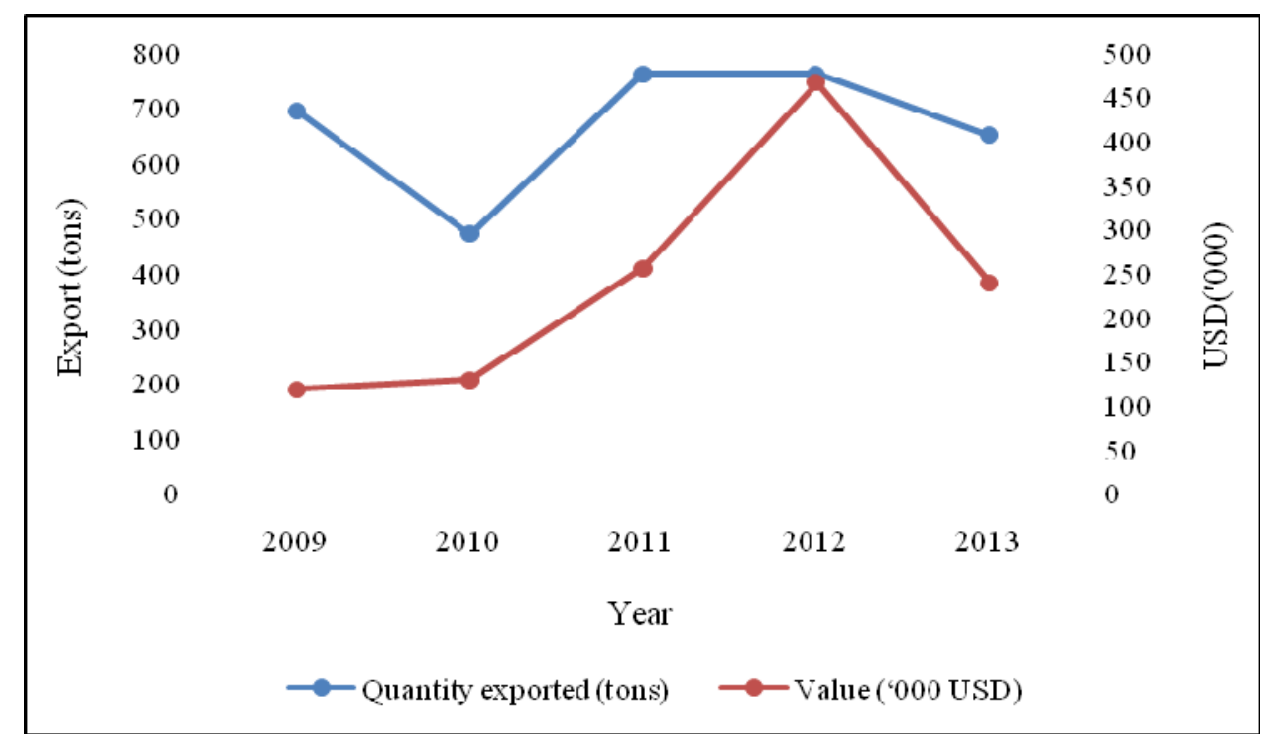

Figure 5. Banana Exports by Quantity vs Value earned (x1000 USD), 2009-2013. Source:(Uganda Bearuea of Statistics, 2014).

This technique can be a good option for delayingthe postharvest ripening of banana fruit for both the small scale farmers and commercial ripening houses in Uganda.

\section{Storing banana fruits treated in exogenous oxalic acid}

This is achieved by dipping banana fruits into solutions of $20 \mathrm{mM}$ oxalic acid for a period of $10 \mathrm{~min}$ then storing them at room temperature of $\left(23 \pm 2{ }^{\circ} \mathrm{C}\right)$ and $75-90 \%$ $\mathrm{RH}$ (Huang et al., 2013). The oxalic acid application to bananas curbed deterioration in storage, limited the respiration rates and production of ethylene, as well as reduced rate of firmness, hue angle, and maximal chlorophyll fluorescence loss. This treatment generally best prevents postharvest losses in banana due to faster ripening and can therefore be a good commercial tool to help store bananas in large scale (Huang et al., 2013). It is predorminantly used in China, India and Pakistan with very limited application in Africa (Huang et al., 2013). This technique can be a very good way of controlling banana ripening in Uganda since its simpler and cheap.

\section{Estimating The Potential of Controlledbanana Ripening And Juice Extraction In Uganda}

Appropriate controlled ripening and delayed techniques and their economic impact to Uganda

it is of great interest for farmers to reap maximum benefits from their produce. Potentially banana juice extraction depends on the ripening techniques. The predominant ripening techniques used in Uganda is natural ripening which is not sustainable (KyamuhangireandPehrson, 1999). Therefore, introduction of controlled ripening and delaying techniques can contribute greatly to the amount of ripened banana available for juice, wine and beer processing.

In view of the different ripening and delay techniques illustrated in this paper, not all of them can be applied in Uganda. The use of ethylene gas can be a good strategy to boost banana ripening for industrial use. This is because, ethylene gas can be easily afforded by many small scale farmers. On the other hand, for delayed ripening controlled temperature and air flow rate is the most appropriate techniques that small scale farmers can adopt in Uganda. This is because despite poor electricity distribution, several cold store centres in small towns in the proximity of farmers can serve well.

In addition, controlled ripening and cold storage techniques can boost foreign exchange earned from banana export which is in a decreasing trend as illustrated in Figure 5.

With improved banana ripening and juice processing techniques, average employment opportunities and labour cost indexin Uganda can increase substantially as shown in Figure 6, implying an increased income rate for farmers and better pay for workers attached to processing firm. Owing to the robust production of banana in the country, 


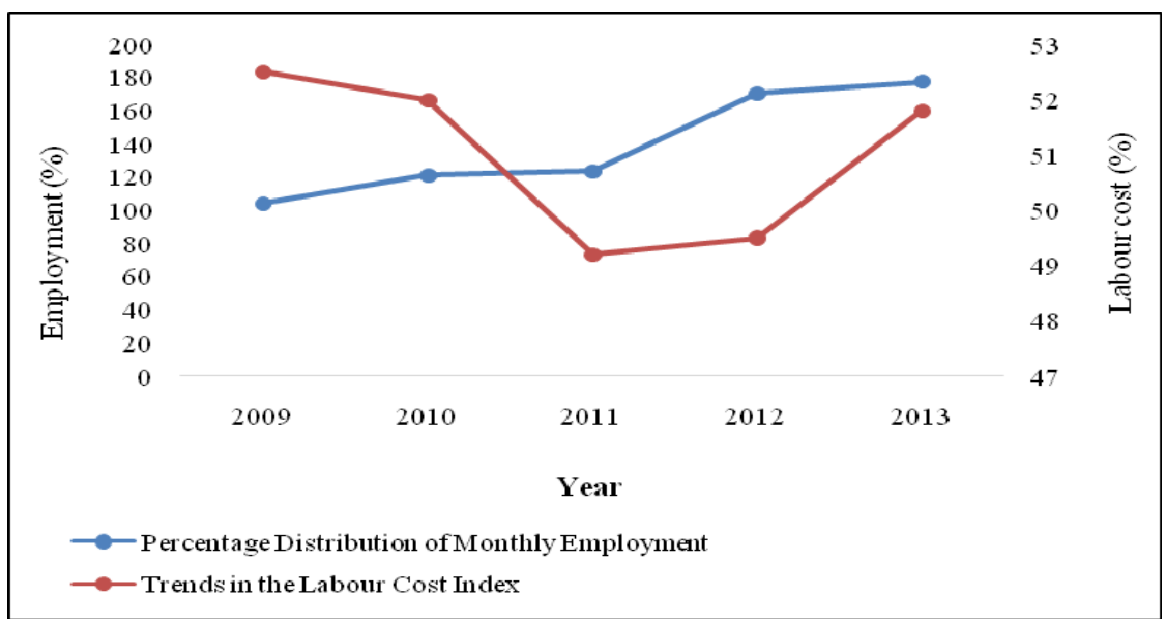

Figure 6. Percentage Distribution of Monthly Employment vs Trends in the Labour Cost Index (for Food processing and beverages).

Source:(Establishment survey, UBOS, 2014).

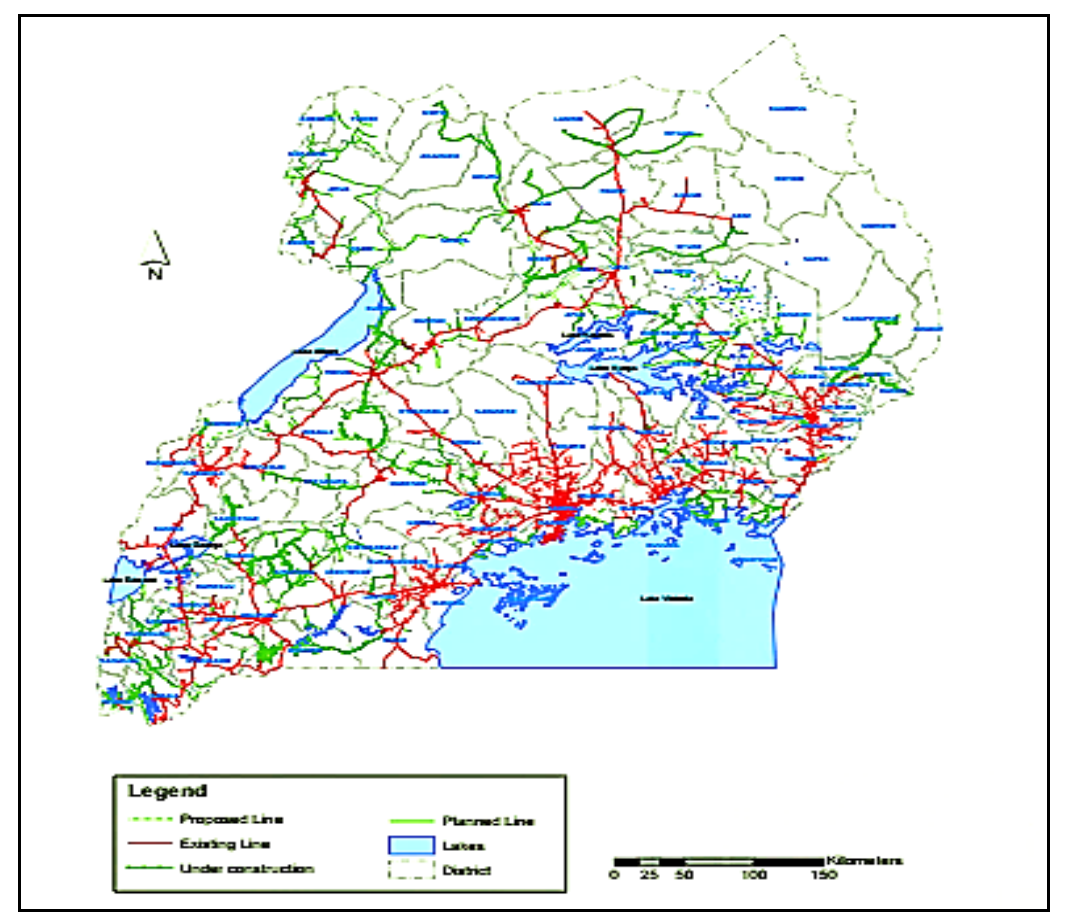

Figure 7. Electrical Distribution Map: Existing, Under Construction and Proposed Lines in Uganda. Sources:Ministry of Energy and Mineral Development, 2010.

\section{Feasibility of Banana Juice extraction and its Economic Impact to Uganda}

Banana juice extraction in Uganda has been done on small scale using simple hand driven machines (Kasozi and Kasisira, 2005) and manually using hands and foots(REFORUM et al., 2010). Nevertheless, in the bid to industrialize banana juice processing, the Matooke
Markets Development Project (MMDP) under the Presidential Initiative for Banana Industrial Development (PIBID) introduced several initiatives (REFORUM et al., 2010). With the pilot plantin Makerere University at the school of Food Technology, Nutrition and BioEngineering (Poverty Alleviation Department, 2008), the project was found suitable. Therefore, the proper industrialized banana juice processing can contribute to 
the country's Gross Domestic Product (GDP) earned by food crops sector which stands at $12.2 \%$ in fiscal year 2013/14 (UBoS, 2014).

Similarly, according to Ssonko, SsebulibaandJager (2005), banana juice production can boost daily per capita fruit consumption in Uganda. Ssonko et al.(2005)noted that thedaily fruit consumption per person in Uganda is $29.4 \mathrm{~g}$ which is far below the recommended amounts by nutritionists for a single person at $80 \mathrm{~g} / \mathrm{day}$.

However, according UBoS (2014), the average annual growth rate and annual yield of bananas areestimated at $0.8 \%$ and 4.5 ton/ha respectivelywith a decreasing trend in production in the last decade (REFORUM et al., 2010). Consequently, with the current banana production rate of $4,375,000$ tonnes per year (2013), the possibility of sustaining large scale banana juice production is limited. According to (Komarek, 2010), the average dailyconsumption of banana per individual in Uganda is $0.7 \mathrm{~kg} / \mathrm{capita} /$ day. Thus, with a population growth rate of $3.2 \%$ (UBoS, 2014)and the adverse climatic changes, the bananas produced cannot be sustainable to feed the country's population and supply the processing plants with raw materials. It is projected that with the current banana growth rate as compared to the population growth rate, the production is not sufficient to feed the population as illustrated in.This consequently can be made worse if banana was to be diverted to industrialized juice processing.

On the other hand, both the ripening and extraction techniques largely depend on the availability of electricity. According (The Government of the Republic of Uganda, 2012) rural electrification plan, only $5 \%$ of the rural are connected to electricity grid as shown in Figure 7

In addition Kaijuka (2007), noted that rural electrification in Uganda is very slow majorly because of the low population densitiesin the rural areas and their poverty state. This has been a big drawback for private sector investment because of exorbitant initial capital and operating costs. Consequently, this can cause a challenge in establishment of juice extraction plants in the rural areas where bananas are produced and as a result high initial cost.

\section{CONCLUSIONS AND RECOMMENDATIONS}

Controlled banana ripening is a very important technique that should be adopted by both small scale and large scale farmers in Uganda. Though the initial costs might be exorbitant, the benefits arelong term. Banana as a major food cropin Uganda is a source of income to scale farmers, therefore, proper controlled ripening techniques can improve the farmer's income and reduce wastages due to poor storage and ripening conditions. However, industrialized banana juice processing might not be sustainable due increase population growth but reduced banana yield with time. Therefore, for sustainable industrialized banana juice processing to be feasible.

However, the possibility of sustainable industrialized juice processing is pegged upon increasing the production of banana by enlarging the uncultivated fallow lands and using improved banana varieties. Similarly, due to the increased drought brought about by climate change, intensified commercial agriculture steered by proper irrigation can be a sufficient strategy to improve production. Lastly, proper balance in production and consumption between banana and other food crops within the country should be achievedto help control the over dependence on banana.

\section{ACKNOWLEDGEMENTS}

The scientific responsibility is accredited to the authors.

\section{REFERENCES}

Abdallah SE(2012). Temperature and Airflow rate effect on artificial ripening process of banana. Agricultural Engineering Research Institute (AEnRI), Giza, Egypt, 43.

Adão RC, Glória MB(2005). Bioactive amines and carbohydrate changes during ripening of "Prata" banana (Musa acuminata $\mathrm{x} \mathrm{M}$. balbisiana). Food Chemistry, 90, 705-711. doi:10.1016/j .food chem.2004.05.020.

Bagamba F, Burger K, TushemereirweWK(2008). Banana (Musa spp.) production characteristics and performance in Uganda. In International Conference on Banana and Plantain in Africa: Harnessing International Partnerships to Increase Research Impact 879 (pp. 187-198).

Bagnato N, Klieber A, Barrett R, Sedgley M(2002). Optimising ripening temperatures of Cavendish bananasvar. "Williams" harvested throughout the year in Queensland, Australia. Australian Journal of Experimental Agriculture, 40, 1017-1022. doi:10.1071/EA01162.

Beer ZCD, Sigawa A(2010). Banana (Musa spp .) Juice Production in South Africa, 233-238.

Cheng G, Duan X, Shi J, Lu W, Luo Y, Jiang W, Jiang Y (2008). Effects of reactive oxygen species on cellular wall disassembly of banana fruit during ripening. Food Chemistry, 109, 319-324. doi:10.1016/j.foodchem.2007.12.041.

Der Agopian RG, Peroni-Okita FHG, Soares CA, Mainardi JA, Do Nascimento JRO, Cordenunsi BR, Purgatto E(2011). Low temperature induced changes in activity and protein levels of the enzymes associated to conversion of starch to sucrose in banana fruit. Postharvest Biology and Technology, 62, 133-140. doi:10.1016/j.postharvbio.2011.05.008.

Gol NB, Ramana Rao TV(2011). Banana Fruit Ripening as Influenced by Edible Coatings. International Journal of Fruit Science, 11, 119135. doi:10.1080/15538362.2011.578512.

Gonzalez-Aguilar GA, Villa-Rodriguez JA, Ayala-Zavala JF, Yahia EM(2010). Improvement of the antioxidant status of tropical fruits as a secondary response to some postharvest treatments. Trends in Food Science and Technology, 21(10), 475-482. doi:10.1016/j.tif s 2010.07.004.

Harris DR, Seberry JA, Wills RBH, Spohr LJ(2000). Effect of fruit maturity on efficiency of 1-methylcyclopropene to delay the ripening 
of bananas. Postharvest Biology and Technology, 20, 303-308. doi:10.1016/S0925-5214(00)00150-2.

Huang H, Jing G, Guo L, Zhang D, Yang B, Duan X, Jiang Y(2013). Effect of oxalic acid on ripening attributes of banana fruit during storage. Postharvest Biology and Technology, 84, 22-27. doi:10.1016/j.postharvbio.2013.04.002

Imahori Y, Yamamoto K, Tanaka H, Bai J(2013). Residual effects of low oxygen storage of mature green fruit on ripening processes and ester biosynthesis during ripening in bananas. Postharvest Biology and Technology, 77, 19-27. doi:10.1016/j.postharvbio.2012.11.004.

Kaijuka $E(2007)$. GIS and rural electricity planning in Uganda. Journal of Cleaner Production, 15, 203-217. doi:10.1016/j.jclepro.2005.11.057

Kasozi G, Kasisira, L. L. (2005). Design and performance of a banana juice extractor. African Crop Science Conference Proceedings, 7 , 1381-1384.

Komarek $A(2010)$. The determinants of banana market commercialisation in Western Uganda. African Journal of Agricltural Research, 5(9), 775-784. doi:10.5897/AJAR09.022.

Kyamuhangire W, PehrsonR (1999). Conditions in banana ripening using the rack and pit traditional methods and their effect on juice extraction. Journal of the Science of Food and Agriculture, 79(2), 347-352. doi: 10.1002/(SICI)1097-0010(199902)79:2<347::AIDJSFA206>3.0.CO;2-Q.

Kyamuhangire W, Myhre H, Sørensen H T, Pehrson R(2002). Yield, characteristics and composition of banana juice extracted by the enzymatic and mechanical methods. Journal of the Science of Food and Agriculture, 82(October 2001), 478-482. doi:10.1002/jsfa. 1052.

Larotonda FDS, Genena AK, Dantela D, Soares HM, Laurindo JB, Moreira RFPM., Ferreira SRS(2008). Study of banana (Musa aaa Cavendish cv Nanica) trigger ripening for small scale process. Brazilian Archives of Biology and Technology, 51(October), 10331047. doi:10.1590/S1516-89132008000500021.

Mahajan BVC, Tajender K, Gill MIS, Dhaliwal HS, Ghuman BS, Chahil BS(2010). Studies on optimization of ripening techniques for banana. Journal of Food Science and Technology, 47(June), 315319. doi:10.1007/s13197-010-0050-0.

Ministry of Energy and Mineral Development(2010). Annual Rural Electrification Report 2010/11. Kampala, Uganda.

Palomer X, Roig-Villanova I, Grima-Calvo D, Vendrell, M(2005). Effects of nitrous oxide (N2O) treatment on the postharvest ripening of banana fruit. Postharvest Biology and Technology, 36, 167-175. doi:10.1016/j.postharvbio.2004.12.008.

Peroni-Okita FHG, Cardoso MB, Agopian RGD, Louro RP, Nascimento JRO, Purgatto E, Cordenunsi (2013). The cold storage of green bananas affects the starch degradation during ripening at higher temperature. Carbohydrate Polymers, 96(1), 137-147. doi:10.1016 / j.carbpol.2013.03.050.

Pongprasert N, Srilaong V(2014). A novel technique using 1-MCP microbubbles for delaying postharvest ripening of banana fruit. Postharvest Biology and Technology, 95, 42-45. doi: 10. 1016 /j. postharvbio.2014.04.003.

Poverty Alleviation Department(2008). Matooke Markets Development Project; Presidential Initiative for Banana Industrial Development (PIBID), (September).
REFORUM C, Kabahenda M, Kapiriri MN, Kabahenda M(2010). Analysing Agricultural Science and Technology Innovation Systems: A Case Study of the Banana Sub-sector in Uganda. Kampala, Uganda.

Salveit ME (2004). Respiratory metabolism. The Commercial Storage of Fruits, Vegetables, and Florist and Nursery Stocks. Agriculture Handbook Number 66.

Sen C, Mishra HN, Srivastav PP(2012). Modified atmosphere packaging and active packaging of banana (Musa spp.): A review on control of ripening and extension of shelf life. Journal of Stored Products and Postharvest Research, 3(9), 122-132. doi:10 .5897/ JSPPR11.057.

Silveira AC, Araneda C, Hinojosa A, Escalona VH(2014). Effect of nonconventional modified atmosphere packaging on fresh cut watercress (Nasturtium officinale R. Br.) quality. Postharvest Biology and Technology, 92, 114-120. doi:10. 1016/j.pos tharvbio .2013. 12.012.

Ssonko, RN, Njue E, Ssebuliba JM, De JagerA(2005). Pro-poor Horticulture in East Africa and South Asia: the Horticultural Sector in Uganda. International Society for Horticultural Science.

Stewart OJ, Raghavan GSV, Golden KD, Gariépy Y(2005). MA storage of Cavendish bananas using silicone membrane and diffusion channel systems. Postharvest Biology and Technology, 35, 309317. doi:10.1016/j.postharvbio.2004.10.003.

Suseno N, Savitri E, Sapei L, Padmawijaya, KS(2014). Improving Shelflife of Cavendish Banana Using Chitosan Edible Coating. Procedia Chemistry, 9, 113-120. doi:10.1016/j.proche.2014.05.014.

The Government of the Republic of Uganda (2012). Rural Electrification Strategy and Plan, Covering the Period 2013-2022. Kampala, Uganda. Retrieved from http://rea.or.ug/phocadownload/rural electrification strategy and plan 2013-2022.pdf.

Uganda Bureau of Statistics, (2014). Statistical Abstract, 2014 Kampala, Uganda.

USDA National Nutrient Database (2014). Release23. http:/ /www.ars.u sda.gov/SP2UserFiles/Place/12354500/Data/SR24/reports/sr24fg09 . pdf as viewed on 10 March, 2015.

Will RBH. Warton MA, Musa DMDN, Chew LP(2001). Ripening of climacteric fruits initiated at low ethylene levels. Australian Journal of Experimental Agriculture, 41, 89-92.

Yang XT, Zhang ZQ, Joyce D, Huang XM, Xu LY, Pang XQ(2009). Characterization of chlorophyll degradation in banana and plantain during ripening at high temperature. Food Chemistry, 114(2), 383390. doi:10.1016/j.foodchem.2008.06.006. 